\title{
Pengaruh Tingkat Perputaran Modal Kerja, Leverage, Tingkat Perputaran Kas, dan Pertumbuhan Perusahaan Pada Rentabilitas Ekonomi
}

\author{
Ketut Sintya Gita Prabasini ${ }^{1}$ \\ I Gusti Ayu Eka Damayanthi ${ }^{2}$ \\ ${ }^{1,2}$ Fakultas Ekonomi dan Bisnis Universitas Udayana (Unud), Bali, Indonesia \\ e-mail: sintyagita14@gmail.com
}

\begin{abstract}
ABSTRAK
Tujuan dari penelitian ini adalah untuk mengetahui pengaruh tingkat perputaran modal kerja, leverage, perputaran kas, dan pertumbuhan perusahaan pada rentabilitas ekonomi pada perusahaan Pertambangan Batubara yang terdaftar di Bursa Efek Indonesia periode 2015 2017. Pendekatan penelitian yang digunakan dalam penelitian ini adalah pendekatan kuatitatif dengan menggunakan data sekunder. Teknik sampling yang digunakan adalah non probability sampling dengan metode purposive sampling. Jumlah sampel yang digunakan adalah 54 sampel. Teknik Analisis yang digunakan adalah regresi linear berganda. Berdasarkan hasil penelitian, penelitian ini menunjukan bahwa variabel tingkat perputaran modal kerja, perputaran kas, dan pertumbuhan perusahaan berpengaruh positif dan signifikan pada rentabilitas ekonomi sedangkan variabel leverage tidak berpengaruh signifikan pada rentabilitas ekonomi.
\end{abstract}

Kata Kunci: Modal kerja, leverage, perputaran kas

\begin{abstract}
The purpose of this study was to determine the effect of the level of turnover of working capital, leverage, cash turnover, and company growth on economic rentability in coal mining companies listed on the Indonesia Stock Exchange for the period 2015-2017. The research approach used in this study was a quantitative approach using secondary data. The sampling technique used is non probability sampling with a purposive sampling method. The number of samples used was 54 samples. The analysis technique used is multiple linear regression. Based on the results of the study, this study shows that the variable level of working capital turnover, cash turnover, and company growth has a positive and significant effect on economic rentability while the leverage variable does not have a significant effect on economic profitability.

Keywords: Working capital, leverage, cash turnover
\end{abstract}

\section{PENDAHULUAN}

Sektor yang dapat dijadikan penopang dalam pembangunan ekonomi adalah sektor pertambangan karena menyediakan sumber daya energi yang diperlukan untuk pertumbuhan perekonomian nasional. Terbukanya peluang pertumbuhan perusahaan yang bergerak pada sektor pertambangan ditunjukkan dengan adanya dukungan dari pemerintah dalam hal menciptakan iklim investasi yang kondusif. Potensi yang kaya akan sumber daya alam akan dapat menumbuhkan terbukanya 
perusahaan-perusahaan untuk melakukan eksplorasi pertambangan sumber daya tersebut. Perusahaan pertambangan terdiri dari pertambangan batubara, minyak dan gas bumi, logam dan mineral lainnya, serta batu-batuan. Dari beberapa sub sektor pertambangan tersebut, batubara mempunyai pengaruh yang cukup besar terhadap perekonomian Indonesia. Perusahaan pertambangan membutuhkan modal yang sangat besar dalam mengeksplorasi sumber daya alam dalam mengembangkan pertambangan. Untuk itu, perusahaan pertambangan banyak masuk ke pasar modal untuk menyerap investasi dan untuk memperkuat posisi keuangannya.

Indonesia memiliki prospek yang besar dalam pengembangan sumber daya mineral, karena selain memiliki potensi sumber daya yang beragam dan besar, kenaikan harga komoditi mineral belakangan ini seharusnya bisa dioptimalkan untuk memberikan manfaat bagi pembangunan ekonomi Indonesia.Tahun 2010, nilai industri pertambangan mencapai lebih dari 73 miliar dollar AS, yang menyumbang sekitar 11 persen terhadap produk domestik bruto Indonesia (detiknews.com). Pertumbuhan yang baik ini mencerminkan tingkat kesehatan yang baik dalam sektor pertambangan, yang didukung oleh tingginya harga komoditas.

Indonesia memperoleh peringkat ke enam terbesar sebagai negara yang memiliki kekayaan sumber daya tambang. Selain hal itu, sektor pertambangan Indonesia digunakan sebagai sektor penggerak perekonomian dalam negeri serta digunakan sebagai komoditi ekspor untuk negara lain. Isu utama terkait dengan adanya pengembangan perusahaan pada sektor pertambangan terutama pada 
perusahaan yang sudah go public karena sifat dan karakteristik yang dimiliki oleh sektor atau industri tersebut yang padat modal atau memerlukan biaya investasi yang sangat besar, berjangka panjang, padat resiko atau sarat risiko serta adanya ketidakpastian yang tinggi atau besar.

Bisnis pertambangan mineral dan batu bara di Indonesia memasuki babak baru dengan terbitnya Undang-undang Nomor 4 Tahun 2009 tentang Pertambangan Mineral dan Batu Bara (Minerba). Undang-undang ini menggantikan UU Nomor 11 Tahun 1967 tentang Pertambangan Umum. Dalam UU tersebut terdapat kewajiban bagi investor untuk memproses semua produk pertambangan menjadi logam di Indonesia, baik dengan mendirikan pabrik peleburan (smelter) sendiri atau menggunakan fasilitas peleburan pihak lain. Pemerintah juga menerbitkan aturan bea keluar atas 14 komoditas tambang mineral seperti nikel, tembaga, bijih besi dan bauksit dalam bentuk bahan mentah pada bulan Mei 2012. Terbitnya peraturan Menteri Energi dan Sumber Daya Mineral ini bertujuan untuk mengendalikan ekspor mineral dalam bentuk bahan mentah menjelang penerapan larangan ekspor komoditas tambang tahun 2014.

Industri pertambangan merupakan Industri yang kegiatannya berkelanjutan, maka sangat dibutuhkan pengelolaan yang sangat baik. Modal kerja merupakan hal yang paling penting karena dengan adanya modal kerja dapat dilakukan perputaran modal kerja untuk membiayai segala aktifitas usaha. Periode perputaran modal kerja dimulai pada saat kas yang tersedia diinvestasikan dalam komponen modal kerja sampai saat dimana kembali lagi menjadi kas. Periode perputaran modal kerja dipengaruhi oleh periode perputaran masing-masing 
Ketut Sintya Gita Prabastini dan I Gusti Ayu Eka Damayanthi. Pengaruh ...

komponen dari modal kerja tersebut (Riyanto, 2001). Lamanya periode perputaran tergantung kegiatan operasi. Kondisi perusahaan pertambangan dapat diartikan sebagai kinerja perusahaan, merupakan faktor yang sangat penting sebagai alat untuk mengetahui apakah perusahaan mengalami kemajuan atau sebaliknya. Ukuran kinerja perusahaan yang biasa digunakan, diukur dari laporan keuangan perusahaan.

Tujuan suatu perusahaan pada umumnya adalah untuk memperoleh laba. Demikian halnya dengan Perusahaan Pertambangan Batu Bara, di dalam menjalankan aktivitas usahanya harus memperhatikan bagaimana upaya yang dapat dilakukan agar posisinya tetap menguntungkan sehingga kelangsungan dapat terjaga. Akan tetapi laba yang besar belum merupakan ukuran perusahaan atau lembaga keuangan itu telah bekerja secara efisien. Efisiensi baru dapat diketahui dengan membandingkan laba yang diperoleh dengan kekayaan atau modal yang menghasilkan laba tersebut, untuk mengetahui efisien atau tidaknya hal tersebut dapat dihitung dengan rentabilitas. Besarnya rentabilitas tergantung dari besar kecilnya untung dan modal (Amidipradja, Wirasasmita, \& Rivai, 2005). Menurut (Hadiwidjaja, 2001) menjelaskan Pengukuran dengan ratio rentabilitas ekonomi ialah untuk mengetahui kemampuan perusahaan dalam menciptakan laba dibandingkan dengan modal yang digunakan. (Wasis, 1993) menyatakan rentabilitas merupakan kemampuan perusahaan untuk memperoleh laba dengan modal yang ditanamkan.

Perkembangan industri pertambangan batubara dalam dua tahun terakhir kembali menjadi sorotan dalam dunia bisnis karena menurunnya kinerja dari 
perusahaan batubara. Hal tersebut disebabkan oleh perlambatan ekonomi di Cina serta menurunnya harga jual batubara. Perlambatan ekonomi Cina yang merupakan mitra dagang yang paling penting bagi Indonesia (Cina berkontribusi untuk hampir sepersepuluh dari total ekspor Indonesia) membawa dampak negatif, yaitu menurunnya nilai ekspor produk batubara Indonesia karena kebijakan baru Cina yang membatasi impor batubara.

Dalam Laporan tahunan Price Waterhouse Coopers (PWC) dikatakan bahwa pada tahun 2015 lalu sebagai tahun terburuk bagi sektor pertambangan. Dalam Laporan ke-13 dari rangkaian laporan Industri PWC seperti yang diterima oleh Majalah Tambang, 40 perusahaan pertambangan global terbesar mencatat kerugian bersih kolektif (27 miliar dollar AS). Ini merupakan yang pertama dalam sejarah di mana kapitalisasi pasar turun sebesar 37 persen. Dan lebih dari itu penurunan ini bahkan telah secara efektif menghapus keuntungan yang diperoleh selama siklus super komoditas. Jock O’Callaghan, Global Mining leader di PWC mengatakan Penurunan harga komoditas sebesar 25 persen dibandingkan tahun sebelumnya. Ini yang mendorong perusahaan pertambangan harus berupaya keras meningkatkan produktivitas, beberapa di antaranya berjuang untuk bertahan, diikuti dengan pelepasan aset atau penutupan usaha. Kondisi yang demikian kemudian berimbas pada perusahaan tambang Indonesia. Di tahun 2015 tidak ada perusahaan pertambangan di Indonesia dengan kapitalisasi pasar melebihi 4 miliar dollar AS. Angka tersebut merupakan batas terendah agar dapat masuk dalam jajaran 40 perusahaan pertambangan terbesar di dunia berdasarkan kapitalisasi pasar. Sacha Winzenried, Lead Adviser for Energy, Utilities dan Mining PWC 
Ketut Sintya Gita Prabastini dan I Gusti Ayu Eka Damayanthi. Pengaruh ...

Indonesia menjelaskan kapitalisasi pasar keseluruhan perusahaan pertambangan yang tercatat di Bursa Efek Indonesia turun dari Rp255 triliun pada tanggal 31 Desember 2014 menjadi Rp161 triliun pada tanggal 31 Desember 2015. Penurunan sebesar 37 persen ini terutama dipicu oleh jatuhnya harga komoditas (Rembeth, 2015).

Krisis mengenai pertambangan yang berkelanjutan disertai menurunnya harga batubara, turunnya angka ekspor membuat beberapa perusahaan tambang batubara terpaksa ditutup. Hal di atas menimbulkan kesulitan yang cukup besar terhadap perusahaan pertambangan batubara. Era globalisasi saat ini, perusahaan harus mampu meningkatkan kinerja melalui efisiensi operasional usaha guna mengoptimalkan profit untuk menjaga kelangsungan dan perkembangan usahanya. (Owolabi \& Alu, 2012) mengungkapkan sebuah bisnis idealnya membutuhkan sumber daya yang cukup untuk menjamin kelangsungan usaha dan memastikan bahwa sumber daya tersebut dimanfaatkan secara optimal guna meningkatkan rentabilitas dan kinerja secara keseluruhan. Informasi mengenai rentabilitas sangat berguna dalam pengambilan keputusan berkenaan dengan perubahan potensial pada sumber daya ekonomi sehingga perusahaan akan mampu memegang kendali di masa depan (Burja, 2011). Selain itu, dengan adanya informasi rentabilitas ini dapat bermanfaat bagi para investor, kreditur atau pengguna laporan keuangan lainnya dalam membuat suatu keputusan untuk melakukan investasi.

Tingkat perputaran modal kerja, leverage, tingkat perputaran kas dan pertumbuhan perusahaan digunakan untuk menilai kemampuan Perusahaan 
Pertambangan Batubara dalam mengelola tingkat perputaran modal kerja, leverage, tingkat perputaran kas dan pertumbuhan perusahaan secara efisien. Tingkat Perputaran modal kerja merupakan aspek penting pada keuangan perusahaan yang menggambarkan efektifitas penggunan modal kerja yang dimiliki perusahaan untuk menghasilkan penjualan. Leverage menunjukkan kemampuan perusahaan untuk memenuhi segala kewajiban finansialnya apabila sekiranya perusahaan tersebut dilikuidasi, dengan demikian pengertian solvabilitas (leverage) dimaksudkan sebagai kemampuan suatu perusahaan untuk membayar hutang- hutangnya baik jangka pendek maupun jangka panjang (Riyanto, 2001). Tingkat perputaran kas menunjukan tingkat kecukupan modal kerja perusahaan yang dibutuhkan untuk membayar tagihan dan membiayai penjualan. Tingkat pertumbuhan perusahaan menunjukan peramalan laba dimasa yang akan datang, penilaian efisiensi dalam menjalankan usaha. Dengan demikian makin tinggi tingkat perputaran modal kerja, leverage, tingkat perputaran kas dan pertumbuhan perusahaan menunjukkan rentabilitas yang tinggi dicapai oleh Perusahaan Pertambangan Batubara berarti semakin tinggi pula tingkat efisiensi penggunaan modalnya.

Penelitian yang dilakukan oleh (Wibowo \& Wartini, 2012), menyatakan bahwa secara parsial efisiensi modal kerja berpengaruh signifikan terhadap rentabilitas dan secara parsial leverage tidak berpengaruh signifikan terhadap rentabilitas. Penelitian yang dilakukan oleh (Supriadi \& Sofyana, 2012) mengatakan bahwa Solvabilitas (leverage) berpengaruh signifikan terhadap rentabilitas. Penelitian terdahulu yang menguji mengenai rentabilitas ekonomi 
Ketut Sintya Gita Prabastini dan I Gusti Ayu Eka Damayanthi. Pengaruh ...

telah beberapa kali dilakukan. Namun, hasil yang didapat dari beberapa penelitian tidak konsisten.

Penelitian ini merupakan replikasi dari penelitian yang dilakukan oleh (Hadinata \& Wirawati, 2016) yang berjudul Pengaruh Tingkat Perputaran Kas, Perputaran Piutang, Likuiditas, dan Pertumbuhan Koperasi pada Rentabilitas Ekonomi. Perbedaan antara penelitian ini dengan penelitian sebelumnya yaitu sampel dari penelitian ini adalah perusahaan pertambangan batu bara sedangkan penelitian sebelumnya menggunakan sampel pada Koperasi Pasar Srinadi Klungkung, pemilihan sampel perusahaan pertambangan batu bara terkait dengan fenomena menurunnya harga komoditas yang saat ini terjadi di Indonesia dengan beberapa kasus yang telah diuraikan di atas. Penelitian ini menambahkan beberapa variabel yaitu tingkat perputaran modal kerja dan leverage. Alasan menggunakan variabel tingkat perputaran modal kerja yaitu modal kerja merupakan aspek yang paling penting bagi tiap perusahaan karena modal kerja merupakan faktor penentu berjalannya kegiatan operasional dalam jangka pendek dalam perusahaan.Kegiatan operasional tersebut berpengaruh pada pendapatan yang diperoleh perusahaan. Sedangkan alasan menggunakan variabel leverage yaitu leverage merupakan gambaran mengenai besar atau kecilnya pemakaian hutang oleh suatu perusahaan yang digunakan untuk membiayai aktivitas operasionalnya. Leverage yang semakin tinggi akan menimbulkan masalah keuangan, sehingga nilai perusahaan pun menurun (Sujoko \& Soebiataro, 2007). Untuk mengukur kinerja hutang dalam rangka meningkatkan keuntungan dapat dinilai dengan pengukuran leverage 
perusahaan. Variabel perputaran piutang dan likuiditas yang ada pada penelitian (Hadinata \& Wirawati, 2016) tidak digunakan dalam penelitian ini karena hasil penelitian yang didapatkan sudah konsisten dengan penelitian penelitian sebelumnya. Menurut (Hadinata \& Wirawati, 2016), (Nisa, 2012), dan (Karjono \& Fakrina, 2012) menyimpulkan bahwa tingkat perputaran piutang berpengaruh signifikan positif terhadap rentabilitas ekonomi.Menurut penelitian yang dilakukan oleh (Wibowo \& Wartini, 2012), (Hadinata \& Wirawati, 2016) dan (Hariwangsa \& Wirawati, 2017) menyimpulkan bahwa likuiditas tidak berpengaruh signifikan pada rentabilitas ekonomi.

Efisiensi modal kerja dapat dinilai dengan menggunakan rasio antara total penjualan dengan jumlah modal kerja rata-rata yang sering disebut working capital turnover (perputaran modal kerja). Rasio ini menunjukkan hubungan antara modal kerja dengan penjualan yang dapat diperoleh perusahaan untuk tiap rupiah modal kerja. (Bose, 2013) mengungkapkan bahwa perputaran modal kerja merupakan aspek penting pada keuangan perusahaan yang menggambarkan efektifitas penggunan modal kerja yang dimiliki perusahaan untuk menghasilkan penjualan. Tingkat rentabilitas yang rendah bila dihubungkan dengan modal kerja dapat menunjukkan kemungkinan rendahnya volume penjualan dibanding dengan ongkos yang digunakan. Sehingga untuk menghindari itu, diharapkan adanya pengelolaan modal kerja yang tepat di dalam perusahaan. Perusahaan yang dikatakan memiliki tingkat rentabilitas tinggi berarti tinggi pula efisiensi penggunaan modal kerja yang digunakan perusahaan tersebut. 
Ketut Sintya Gita Prabastini dan I Gusti Ayu Eka Damayanthi. Pengaruh ...

Hal ini sejalan dengan hasil penelitian (Saravanan, S. \& Ramganesh, 2013) menunjukan working capital turnover ratio yang berpengaruh signifikan pada profitabilitas. (Azhar \& Ramesh, 2011) juga menunjukan working capital turnover ratio memiliki tingkat korelasi positif tinggi terhadap profitablitas. (Nurfarkhana, 2015) yang meneliti tentang "Pengaruh Modal Kerja dengan Laba Usaha Koperasi pada Koperasi Serba Usaha Sejati Mulia Jakarta" memiliki kesimpulan bahwa terdapat hubungan yang signifikan antara modal kerja dengan laba usaha/SHU Koperasi. Hal ini didukung oleh penelitian (Menuh, 2002) yang menyebutkan bahwa perputaran modal kerja berpengaruh postif terhadap rentabilitas. Berdasarkan kajian teoritis dan empiris tersebut, maka hipotesis yang diajukan yaitu:

$\mathrm{H}_{1}$ : Tingkat perputaran modal kerja berpengaruh positif pada rentabilitas ekonomi.

Menurut (Kasmir, 2012), leverage merupakan rasio yang digunakan untuk mengukur sejauh mana aktiva perusahaan dibiayai oleh hutang. Artinya berapa besar beban hutang yang ditanggung perusahaan dibandingkan dengan aktivanya. Dalam arti luas rasio leverage, digunakan untuk mengukur kemampuan perusahaan untuk membayar seluruh kewajibannya baik jangka pendek maupun jangka panjang apabila perusahaan dibubarkan (likuidasi).

Teori sinyal adalah suatu teori yang berhubungan dengan pendapat investor dalam memandang prospek atau kinerja perusahaan yang akan dipilih dalam menanamkan dananya. Teori ini menyimpulkan bahwa seorang investor dapat membedakan perusahaan - perusahaan mana saja yang memiliki nilai perusahaan tinggi dan nilai perusahaan rendah. Dari hal tersebut investor dapat 
secara mudah menanamkan dananya ke perusahaan yang bisa menguntungkan investor. Jika manajer menggunakan utangnya secara maksimal maka nilai perusahaan akan bernilai positif di kalangan investor sehingga memungkinkan investor untuk menginvestasikan dananya ke perusahaan.Sedangkan sinyal positif juga bisa terjadi ketika perusahaan tersebut mengeluarkan investasi yang dapat meningkatkan harga saham dan nilai perusahaan juga akan mempunyai signal positif di kalangan masyarakat. Hal itu dapat terjadi karena pertumbuhan perusahaan di masa yang akan datang akan terus berkembang.

(Laksono, 2013) menyatakan bahwa secara parsial solvabilitas berpengaruh positif dan signifikan terhadap rentabilitas. Penelitian ini juga didukung oleh (Wibowo \& Wartini, 2012) dengan judul “Analisis pengaruh efisiensi modal kerja, likuiditas dan leverage terhadap rentabilitas pada perusahaan manufaktur yang terdaftaar di BEI tahun 2007-2009" mengatakan bahwa secara simultan efisiensi modal kerja, likuiditas, dan leverage berpengaruh signifikan terhadap rentabilitas. Berdasarkan kajian teoritis dan empiris tersebut, maka hipotesis yang diajukan yaitu:

$\mathrm{H}_{2}$ : Leverage berpengaruh positif terhadap Rentabilitas Ekonomi.

Perputaran kas adalah jumlah kas yang berputar dalam periode satu tahun. Dengan menghitung tingkat perputaran kas akan diketahui sampai berapa jauh tingkat efisiensi yang dapat dicapai perusahaan dalam upaya mendayagunakan persediaan kas yang ada untuk mewujudkan tujuan perusahaan. Perputaran kas yang makin tinggi akan semakin baik, karena menunjukkan semakin efisiensi dalam penggunaan kas, begitu pula sebaliknya dengan makin rendahnya 
Ketut Sintya Gita Prabastini dan I Gusti Ayu Eka Damayanthi. Pengaruh ...

perputaran kas mengakibatkan banyaknya uang kas yang tidak produktif sehingga akan mengurangi keuntungan perusahaan.

Beberapa penelitian tentang hubungan perputaran kas dan rentabilitas ekonomi menurut (Albertus, Karjono, \& Falah, 2012) dalam penelitan sebelumnya dengan judul Pengaruh Perputaran Kas dan Perputaran Piutang Terhadap Rentabilitas Ekonomi Pada KPRI di Lingkungan BKN mengatakan perputaran kas memiliki pengaruh yang signifikan terhadap rentabilitas ekonomi. Hal ini didukung oleh penelitian (Erlanda, 2010) yang menyebut bahwa perputaran kas berpengaruh signifikan positif terhadap rentabilitas ekonomi. Ini menunjukan bahwa semakin tinggi tingkat perputaran kas berarti makin cepat kembalinya kas masuk pada perusahaan. Berdasarkan kajian teoritis dan empiris tersebut, maka hipotesis yang diajukan yaitu:

$\mathrm{H}_{3}$ : Tingkat perputaran kas berpengaruh positif pada rentabilitas ekonomi.

Rasio pertumbuhan digunakan untuk mengukur seberapa besar kemampuan perusahaan dalam mempertahankan posisinya di dalam industri dan dalam perkembangan ekonomi secara umum. Pertumbuhan aset yang baik akan memberi sinyal kepada investor bahwa kinerja perusahaan dalam keadaan yang baik pula. Dari sudut pandang investor, pertumbuhan aset memberikan sinyal positif dikarenakan perusahaan dianggap mampu beroperasi. Pertumbuhan laba menjadi indikator dari perolehan rentabilitas di perusahaan. Dengan demikian pihak luar dengan mudah akan menanamkan modalnya dikarenakan melihat perkembangan atau pertumbuhan perusahaan melalui rentabilitasnya. Hal ini 
menunjukan pengaruh yang positif antara pertumbuhan perusahaan dengan rentabilitas ekonomi.

Penelitian ini sejalan dengan penelitian yang dilakukan oleh (Takarini \& Ekawati, 2013) yang menguji mengenai pertumbuhan aset yang mendapat hasil bahwa pertumbuhan aset berpengaruh signifikan positif terhadap rentabilitas ekonomi. Ini menunjukan bahwa semakin tinggi tingkat pertumbuhan aset menunjukkan bahwa perusahaan efisien dalam penggunaan modal kerja. Hal ini didukung oleh penelitian yang dilakukan oleh (Sari \& Abundanti, 2014) yang menguji tentang Pengaruh Pertumbuhan Perusahaan dan Leverage Terhadap Profitabilitas dan Nilai Perusahaan pada Sektor Perusahaan Food and Baverages yang terdaftar di Bursa Efek Indonesia. Hasil analisis tersebut menyatakan bahwa pertumbuhan perusahaan berpengaruh positif signifikan terhadap profitabilitas. Berdasarkan kajian teoritis dan empiris tersebut, maka hipotesis yang diajukan yaitu:

$\mathrm{H}_{4}$ : Tingkat pertumbuhan perusahaan berpengaruh positif pada rentabilitas ekonomi.

\section{METODE PENELITIAN}

Penelitian ini dilakukan pada Perusahaan Pertambangan Batu Barayang terdaftar di Bursa Efek Indonesia (BEI). Penelitian ini dilakukan dengan mengambil data yang dapat diunduh melalui situs resmi BEI yaitu www.idx.co.id periode 20152017.Variabel bebas pada penelitian ini yaitu tingkat perputaran modal kerja $\left(\mathrm{X}_{1}\right)$, leverage $\left(\mathrm{X}_{2}\right)$, tingkat perputaran kas $\left(\mathrm{X}_{3}\right)$, dan pertumbuhan perusahaan $\left(\mathrm{X}_{4}\right)$. Variabel terikat pada penelitian ini adalah rentabilitas ekonomi. 
Ketut Sintya Gita Prabastini dan I Gusti Ayu Eka Damayanthi. Pengaruh ...

Perputaran modal kerja dapat dirumuskan (Kasmir, 2012) sebagai berikut :

$$
\text { Perputaran Modal Kerja }=\frac{\text { Penjualan }}{\text { Aktiva lancar-Hutang Lancar }}
$$

Leverage dapat dirumuskan (Horne \& John, 2012) sebagai berikut:

DER $=\frac{\text { Total hutang }}{\text { Total aktiva }} \times 100 \%$

Menurut (Hery, 2012) perputaran kas diukur dengan menggunakan rumus sebagai berikut :

$$
\text { Perputaran Kas }=\frac{\text { Penjualan }}{\text { Rata-rata kas }}
$$

Menurut Warsidi dan Pramuka (2000:45) pertumbuhan perusahaandapat dirumuskan sebagai berikut:

$$
\text { Pertumbuhan Aset }=\frac{\text { Total Aset Periode } \mathrm{t}-\text { Total Aset Periode } \mathrm{t}-1}{\text { Total Aset Periode } \mathrm{t}-1}
$$

Return On Equaty dapat dihitung dengan menggunakan rumus(Riyanto, 2001:38):

$$
\text { ROE }=\frac{\text { Laba Bersih }}{\text { Total Ekuitas }} \times 100 \%
$$

Populasi dalam penelitian ini adalah seluruh perusahaan pertambangan batu bara yang terdaftar di Bursa Efek Indonesia selama periode tahun 2015-2017 yang berjumlah 22 perusahaan. Sampel dalam penelitian ditentukan berdasarkan metode penentuan sampel non probability sampling, yaitu metode penentuan sampel dengan tidak memberikan kesempatan yang sama bagi setiap anggota populasi untuk dipilih sebagai sampel penelitian.

Metode pengumpulan data yang digunakan dalam penelitian ini adalah metode dokumentasi. Data dokumentasi adalah data yang memuat informasi 
mengenai suatu objek atau kejadian masa lalu yang dikumpulkan, dicatat, atau disusun dalam bentuk arsip dan cara dokumentasi biasanya dilakukan untuk mengumpulkan data sekunder dari berbagai sumber. Dalam penelitian ini, penulis menganalisis data-data tertulis seperti laporan keuangan pada perusahaan pertambangan batu barayang terdaftar di Bursa Efek Indonesia tahun 2015-2017.

Analisis regresi linear berganda digunakan untuk menganalisis besarnya hubungan dan pengaruh variabel independen yang jumlahnya lebih dari dua terhadap variabel dependen. Analisis ini bertujuan untuk menguji pengaruh antara variabel bebas/ independen yaitu tingkat perputaran modal kerja, leverage, tingkat perputaran kas, pertumbuhan perusahaan, secara parsial maupun simultan terhadap variabel terikat/ dependen yakni rentabilitas ekonomi. Adapun persamaan regresinya yaitu sebagai berikut.

$\mathrm{Y}=\alpha+\beta_{1} \mathrm{X} 1+\beta_{2} \mathrm{X} 2+\beta_{3} \mathrm{X} 3+\beta_{4} \mathrm{X} 4+\varepsilon$

$\begin{array}{lll}\text { Keterangan: } & \mathrm{Y} & =\text { Rentabilitas Ekonomi } \\ \mathrm{X} 1 & & =\text { Tingkat Perputaran Modal Kerja } \\ \mathrm{X} 2 & & \text { Leverage } \\ \mathrm{X} 3 & & \text { Tingkat Perputaran Kas } \\ \mathrm{X} 4 & =\text { Kontumbuhan Perusahaan } \\ \alpha & =\text { Koefisien Regresi (x) } \\ \beta_{1,} \beta_{2,} \beta_{3}, \beta_{4} & \\ \varepsilon & =\text { Error }\end{array}$

\section{HASIL DAN PEMBAHASAN}

Statistik deskriptif berhubungan dengan pengumpulan dan peringkat data yang menggambarkan karakteristik sampel yang digunakan dalam penelitian ini. Analisis ini berguna untuk menjelaskan karateristik sampel terutama mencakup nilai rata-rata (mean), nilai ektrim yaitu nilai minimum dan nilai maksimum, serta 
standar deviasi dari masing-masing variabel. Hasil dari statistik deskriptif tersebut dapat dilihat pada Tabel 1 berikut.

Tabel 1.

Hasil Statistik Deskriptif

\begin{tabular}{lrrrrr}
\hline & N & Minimum & Maximum & Mean & $\begin{array}{c}\text { Std. } \\
\text { Deviation }\end{array}$ \\
\hline Tingkat Perputaran & & & & & \\
Modal Kerja & 54 & $-10,460$ & 146,058 & 6,252 & 21,994 \\
Leverage & 54 & 0,098 & 2,918 & 0,581 & 0,504 \\
Tingkat Perputaran Kas & 54 & 0,245 & 139,682 & 10,786 & 19,401 \\
Pertumbuhan Perusahaan & 54 & $-8,631$ & 17,763 & 0,726 & 4,546 \\
Rentabilitas & 54 & $-0,779$ & 0,650 & 0,004 & 0,300 \\
Valid N (listwise) & 54 & & & & \\
\hline Sumber: & & & & &
\end{tabular}

Sumber:Data diolah, 2018

Variabel tingkat perputaran modal kerja memiliki nilai minimum sebesar 10,460dan nilai maksimum sebesar 146,058. Hal ini menunjukkan bahwa nilai terendah dari variabel tingkat perputaran modal kerja pada perusahaan pertambangan batubara yang terdaftar di BEI periode 2015-2017 yaitu sebesar 10,460yang dimiliki oleh PT Darma Henwa Tbk (DEWA), sedangkan nilai tertingginya sebesar 146,058 yaitu dimiliki oleh PT Bayan Resources Tbk (BYAN). Secara keseluruhan, nilai rata-rata variabel perputaran modal kerja sebesar 6,252 dengan standar deviasi sebesar 21,994, artinya terdapat penyimpangan antara nilai variabel tingkat perputaran modal kerjayang telah diteliti dengan nilai rata-ratanya yaitu sebesar 21,994.

Variabel leverage memiliki nilai minimum sebesar 0,098 dan nilai maksimum sebesar 2,918. Hal ini menunjukkan bahwa nilai terendah dari variabel leverage pada perusahaan pertambangan batubara yang terdaftar di BEI periode 2015-2017 yaitu sebesar 0,098 yang dimiliki oleh PT Harum Energy Tbk (HRUM), sedangkan nilai tertingginya sebesar 2,918 yaitu dimiliki oleh PT Indo Tambangraya Megah Tbk (ITMG). Secara keseluruhan, nilai rata-rata variabel 
leveragesebesar 0,581dengan standar deviasi sebesar 0,504 artinya terdapat penyimpangan antara nilai variabel leverage yang telah diteliti dengan nilai rataratanya yaitu sebesar 0,504 .

Variabel tingkat perputaran kas memiliki nilai minimum sebesar 0,245 dan nilai maksimum sebesar 139,682 . Hal ini menunjukkan bahwa nilai terendah dari variabel tingkat perputaran kas pada perusahaan pertambangan batubara yang terdaftar di BEI periode 2015-2017 yaitu sebesar 0,245 yang dimiliki oleh PT Golden Eagle Energy Tbk (SMMT), sedangkan nilai tertingginya sebesar 139,682 yaitu dimiliki oleh PT Bara Jaya Internasional Tbk (ATPK). Secara keseluruhan, nilai rata-rata variabel tingkat perputaran kas sebesar 10,786 dengan standar deviasi sebesar 19,401, artinya terdapat penyimpangan antara nilai variabel tingkat perputaran kasyang telah diteliti dengan nilai rata-ratanya yaitu sebesar 19,401 .

Variabel pertumbuhan perusahaan memiliki nilai minimum sebesar $-8,631$ dan nilai maksimum sebesar 17,763. Hal ini menunjukkan bahwa nilai terendah dari variabel pertumbuhan perusahaan pada perusahaan pertambangan batubara yang terdaftar di BEI periode 2015-2017 yaitu sebesar -8,631 yang dimiliki oleh PT Harum Energy Tbk (HRUM), sedangkan nilai tertingginya sebesar 17,763 yaitu dimiliki oleh PT Bayan Resources Tbk (BYAN). Secara keseluruhan, nilai rata-rata variabel pertumbuhan perusahaan sebesar 0,726 dengan standar deviasi sebesar 4,546, artinya terdapat penyimpangan antara nilai variabel pertumbuhan perusahaan yang telah diteliti dengan nilai rata-ratanya yaitu sebesar 4,546. 
Ketut Sintya Gita Prabastini dan I Gusti Ayu Eka Damayanthi. Pengaruh ...

Variabel rentabilitas ekonomi memiliki nilai minimum sebesar -0,779 dan nilai maksimum sebesar 0,650 . Hal ini menunjukkan bahwa nilai terendah dari variabel rentabilitas ekonomi pada perusahaan pertambangan batubara yang terdaftar di BEI periode 2015-2017 yaitu sebesar -0,779 yang dimiliki oleh PT Bara Jaya Internasional Tbk (ATPK), sedangkan nilai tertingginya sebesar 0,650yaitu dimiliki oleh PT Bayan Resources Tbk (BYAN). Secara keseluruhan, nilai rata-rata variabel rentabilitas ekonomi sebesar 0,004dengan standar deviasi sebesar 0,300 artinya terdapat penyimpangan antara nilai variabel rentabilitas ekonomi yang telah diteliti dengan nilai rata-ratanya yaitu sebesar 0,300.

Tabel 2.

Hasil Analisis Regresi Linier Berganda

\begin{tabular}{|c|c|c|c|c|c|}
\hline \multirow[t]{2}{*}{ Model } & \multicolumn{2}{|c|}{$\begin{array}{c}\text { Unstandardized } \\
\text { Coefficients }\end{array}$} & \multirow{2}{*}{$\begin{array}{c}\text { Standardized } \\
\text { Coefficients } \\
\text { Beta } \\
\end{array}$} & \multirow[b]{2}{*}{$t$} & \multirow[b]{2}{*}{ Sig. } \\
\hline & $B$ & Std. Error & & & \\
\hline 1 (Constant) & $-0,028$ & 0,104 & & $-0,274$ & 0,785 \\
\hline $\begin{array}{l}\text { Tingkat Perputaran Modal } \\
\text { Kerja }\end{array}$ & 0,215 & 0,102 & 0,248 & 2,111 & 0,040 \\
\hline Leverage & 0,242 & 0,176 & 0,221 & 1,370 & 0,177 \\
\hline Tingkat Perputaran Kas & 0,432 & 0,152 & 0,446 & 2,840 & 0,007 \\
\hline Pertumbuhan Perusahaan & 0,242 & 0,103 & 0,289 & 2,356 & 0,023 \\
\hline$R$ Square & & & & & 0,396 \\
\hline Adjusted R Square & & & & & 0,346 \\
\hline F Statistik & & & & & 8,021 \\
\hline Signifikansi & & & & & 0,000 \\
\hline
\end{tabular}

Berdasarkan hasil analisis regresi linier berganda seperti yang disajikan pada Tabel 2, maka persamaan strukturalnya adalah sebagai berikut :

$$
\begin{gathered}
Y=\beta_{1} X_{1}+\beta_{2} X_{2}+\beta_{3} X_{3}+\beta_{4} X_{4}+\varepsilon \\
Y=0,215 X_{1}+0,242 X_{2}+0,432 X_{3}+0,242 X_{4}+\varepsilon
\end{gathered}
$$

- Hasil uji memberikan hasil dimana diperoleh besarnya adjusted $\mathrm{R}^{2}$ (koefisien determinasi yang telah disesuaikan) pada Tabel 2 adalah 0,346. Ini berarti variasi rentabilitas ekonomi dapat dipengaruhi secara signifikan oleh 
variabel tingkat perputaran modal kerja $\left(\mathrm{X}_{1}\right)$, leverage $\left(\mathrm{X}_{2}\right)$, tingkat perputaran kas $\left(\mathrm{X}_{3}\right)$, dan tingkat pertumbuhan perusahaansebesar 34,6 persen, sedangkan sisanya sebesar 65,4 persen dijelaskan oleh faktor-faktor lain yang tidak dijelaskan dalam model penelitian.

Berdasarkan hasil analisis di atas dapat dikatakan bahwa tingkat perputaran modal kerja berpengaruh positif dan signifikan pada rentabilitas ekonomi. Leverage tidak berpengaruh signifikan pada rentabilitas ekonomi. Tingkat perputaran kas berpengaruh positif dan signifikan pada rentabilitas ekonomi. Tingkat pertumbuhan perusahaan berpengaruh positif dan signifikan pada rentabilitas ekonomi. Tingkat perputaran modal kerja berpengaruh positif dan signifikan pada rentabilitas ekonomi.

Hasil penelitian ini mendukung penelitian yang dilakukan oleh (Saravanan \& Ramganesh, 2013), (Azhar \& Ramesh, 2011), (Nurfarkhana, 2015), (Menuh, 2002) yang menemukan bahwa rasio tingkat perputaran modal kerja berpengaruh positif pada rentabilitas ekonomi. Tersedianya modal kerja yang cukup, penting bagi perusahaan untuk membiayai kegiatan operasionalnya. Maka, pihak perusahaan harus dapat menggunakan modal kerjanya secara efektif dan efisien. Dimana, pengaruh positif modal kerja pada rentabilitas ekonomi disebabkan karena seakin tinggi modal kerja berarti semakin efisien perusahaan pertambangan batubara dalam mengendalikan aset lancarnya, serta mampu memenuhi semua hutang lancar dengan menggunakan aktiva lancar dengan adanya efisiensi modal kerja maka tingkat rentabilitas yang akan diperoleh perusahaan akan semakin besar. Perputaran modal kerja artinya seberapa banyak modal kerja berputar 
selama satu periode. Apabila perputaran modal kerja yang rendah, maka dapat diartikan bahwa perusahaan sedang kelebihan modal kerja. Sedangkan semakin tinggi modal kerja mencerminkan bahwa semakin banyak pendapatan yang akan diperoleh melalui pengelolaan aset yang pada akhirnya akan meningkatkan rentabilitas.

Berdasarkan hasil pengujian dengan menggunakan regresi liniar berganda, diperolehnilai signifikansi sebesar 0,177 dengan nilai koefisien regresi positif sebesar 0,242. Nilai Signifikansi 0,177>0,050 mengindikasikan bahwa $\mathrm{H}_{0}$ diterima dan $\mathrm{H}_{2}$ ditolak. Hasil ini mempunyai arti bahwa leverage tidak berpengaruh signifikan pada rentabilitas ekonomi.

Hasil penelitian ini tidak mendukung penelitian yang dilakukan oleh (Laksono, 2013), (Wibowo \& Wartini, 2012) yang menyatakan bahwa secara parsial leverage berpengaruh positif dan signifikan terhadap rentabilitas. Namun, berdasarkan hasil uji hipotesis yang telah dilakukan pada hipotesis ini, menyatakan bahwa leverage tidak berpengaruh signifikan pada rentabilitas ekonomi. Hasil penelitian ini relevan dengan penelitian yang dilakukan oleh (Indrajaya, 2011), (Nugroho, 2009). Dimana, rasio leverage menunjukkan kemampuan perusahaan dalam membayar seluruh kewajibannya, baik jangka pendek maupun jangka panjang. Semakin besar rasio leverage suatu perusahaan akan menyebabkan semakin besarnya risiko perusahaan mengalami kesulitan untuk melunasi pokok pinjaman dan biaya bunga akibat jumlah aset yang dimiliki perusahaan tidak mampu menjamin hutang-hutangnya. Namun, berdasarkan hasil pengujian menunjukkan leverage tidak berpengaruh pada rentabilitas karena 
perusahaan pertambangan batubara ini tidak tergantung pada dana pinjaman atau hutang untuk memenuhi sumber dananya. Sebagian besar perusahaan pertambangan yang terdaftar di BEI lebih banyak menggunakan sumber dana dari dalam perusahaan daripada dana pinjaman. Ini dikarenakan sebagian besar perusahaan pertambangan batubara memiliki kas yang cukup besar sehingga mampu membiayai seluruh kegiatan operasionalnya. Selain itu, seperti perusahaan PT Indo Tambangraya Megah Tbk (ITMG), meskipun memiliki leverage yang cukup besar yaitu sebesar 2,918 tetapi perusahaan tersebut dapat menghasilkan rentabilitas ekonomi yang cukup besar yaitu sebesar 0,076. Sehingga besar kecilnya jumlah utang yang dimiliki oleh perusahaan tidak akan berpengaruh pada besar kecilnya rentabilitas yang diperoleh perusahaan.

Berdasarkan hasil pengujian dengan menggunakan regresi liniar berganda, diperolehnilai signifikansi sebesar 0,007 dengan nilai koefisien regresi positif sebesar 0,432. Nilai Signifikansi $0,007<0,050$ mengindikasikan bahwa $\mathrm{H}_{0}$ ditolak dan $\mathrm{H}_{3}$ diterima. Hasil ini mempunyai arti bahwa tingkat perputaran kas berpengaruh positif dan signifikan pada rentabilitas ekonomi.

Hasil penelitian ini mendukung penelitian yang dilakukan oleh (Albertus et al., 2012), (Erlanda, 2010) yang menyatakan bahwa perputaran kas berpengaruh signifikan positif terhadap rentabilitas ekonomi. Adanya pengaruh yang positif berarti bahwa perusahaan pertambangan batubara efisien dalam penggunaan kas, sehingga semakin tinggi tingkat perputaran kas berarti makin cepat kembalinya kas masuk pada perusahaan. Dengan demikian kas akan dapat dipergunakan lagi untuk membiayai kegiatan operasional sehingga laba yang 
diterima perusahaan menjadi lebih besar. Dimana, besarnya laba yang diterima akan membuat tingkat rentabilitas ekonomi menjadi tinggi, sehingga tingkat perputaran kas secara langsung mempengaruhi tingkat rentabilitas ekonomi.

Berdasarkan hasil pengujian dengan menggunakan regresi liniar berganda, diperoleh nilai signifikansi sebesar 0,023 dengan nilai koefisien regresi positif sebesar 0,242. Nilai Signifikansi $0,023<0,050$ mengindikasikan bahwa $\mathrm{H}_{0}$ ditolak dan $\mathrm{H}_{4}$ diterima. Hasil ini mempunyai arti bahwa tingkat pertumbuhan perusahaan berpengaruh positif dan signifikan pada rentabilitas ekonomi.

Hasil penelitian ini mendukung penelitian yang dilakukan oleh (Takarini \& Ekawati, 2013), (Sari \& Abundanti, 2014) yang menyatakan bahwa pertumbuhan perusahaan berpengaruh signifikan positif terhadap rentabilitas ekonomi. Ini menunjukan bahwa semakin tinggi tingkat pertumbuhan aset menunjukkan bahwa perusahaan efisien dalam penggunaan modal kerja. Artinya bahwa semakin tinggi pertumbuhan perusahaan maka dapat meningkatkan rentabilitas ekonomi. Sebaliknya, semakin rendah pertumbuhan perusahaan maka dapat menurunkan rentabilitas ekonomi. Adanya pengaruh signifikan menunjukkan bahwa perusahaan pertambangan batubara telah secara efektif dan efisien menggunakan modal kerjanya sehingga dapat mengoptimalkan pertumbuhan aset perusahaan. Selain itu, perusahaan yang memiliki pertumbuhan aset yang baik mengindikasikan bahwa perusahaan telah mampu menjalankan aktivitasnya lebih baik dari sebelumnya, sehingga laba yang dihasilkan lebih besar dari sebelumnya atau dengan kata lain mengalami pertumbuhan. Pertumbuhan aset yang terjadi secara konsisten akan berdampak pada bertumbuhnya perusahaan 
secara konsisten pula sehingga dapat menjadi lebih besar dan mampu bersaing dengan jenis - jenis usaha lainnya.

\section{SIMPULAN}

Tingkat perputaran modal kerja berpengaruh positif dan signifikan pada rentabilitas ekonomi. Hal ini berartibahwa semakin tinggi tingkat perputaran modal kerja maka semakin tinggi pula rentabilitas ekonomi yang dihasilkan.

Leverage tidak berpengaruh signifikan pada rentabilitas ekonomi. Hal ini berarti besar kecilnya jumlah utang yang dimiliki oleh perusahaan tidak akan berpengaruh pada besar kecilnya rentabilitas ekonomi yang dihasilkan perusahaan, dikarenakan perusahaan pertambangan batubara tidak tergantung pada dana pinjaman atau hutang untuk memenuhi sumber dananya karena perusahaan pertambangan batubara memiliki kas yang cukup besar sehingga mampu membiayai seluruh kegiatan operasionalnya.

Tingkat perputaran kas berpengaruh positif dan signifikan pada rentabilitas ekonomi. Hal ini berarti bahwa semakin tinggi tingkat perputaran kas maka semakin semakin cepat kembalinya kas masuk pada perusahaan dan dapat dipergunakan lagu untuk membiayai kegiatan operasionalnnya sehingga rentabilitas ekonomi yang diterima perusahaan menjadi lebih besar.

Tingkat pertumbuhan perusahaan berpengaruh positif dan signifikan pada rentabilitas ekonomi. Hal ini menunjukan bahwa semakin tinggi tingkat pertumbuhan perusahaan maka semakin tinggi pula rentabilitas ekonomi yang dihasilkan. 
Bagi pihak manajemen perusahaan disarankan untuk memperhatikan tingkat pertumbuhan perusahaannya agar dapat meningkatkan rentabilitas ekonomi yang dihasilkan dengan cara meningkatkan kinerja perusahaannya, serta mampu mengelola modal kerja secara efisien.Sebelum melakukan suatu investasi atau penanaman modal ke dalam sebuah perusahaan sebaiknya para calon investor lebih mempertimbangkan faktor-faktor seperti struktur modal perusahaan dan faktor-faktor lainnya yang bisa meningkatkan nilai perusahaan agar nantinya perusahaan bisa memberikan return (tingkat pengembalian) yang baik.

Peneliti selanjutnya disarankan untuk menambah variabel lain diluar variabel yang telah digunakan dengan proksi yang berpengaruh pada rentabilitas ekonomi seperti tingkat perputaran piutang, perputaran persediaan, dll. Selain itu peneliti juga dapat menambah periode pengamatan.

\section{REFERENSI}

Albertus, Karjono, \& Falah, A. (2012). Pengaruh Perputaran Kas dan Perputaran Piutang Terhadap Rentabilitas Ekonomi Pada KPRI Di Lingkungan BKN. Jurnal ESENSI. Institut Bisnis Nusantara Jakarta, 15.

Amidipradja, Wirasasmita, T. dan, \& Rivai. (2005). Neraca Koperasi. Bandung: Pionir Jaya.

Azhar, \& Ramesh, S. and. (2011). Working Capital Management And Profitability - A Case Study Of Andhra Pradesh Power Generation Corporation. International Journal Of Research In Commerce \& Management, 2.

Bose, B. (2013). The Impact of Working Capital Management Practices on Firms Profitability. International Journal of Applied Research and Studies, 2.

Burja, C. (2011). Factors influencing the companies' profitability. Annales Universitatis Apulensis Series Oeconomica, 13(2), 215-224. 
Erlanda, T. (2010). Analisis Efisien Modal Kerja dan Pengaruhnya Terhadap Rentabilitas Ekonomi pada Pusat Koperasi Pegawai Republik Indonesia (PKP-RI) Propinsi Sumatra Barat. Skripsi S1 Manajemen Universitas Andalas.

Hadinata, N. P. T., \& Wirawati, N. G. P. (2016). Pengaruh Tingkat Perputaran Kas, Perputaran Piutang, Likuiditas, Dan Pertumbuhan Koperasi Pada Rentabilitas Ekonomi. E-Jurnal Akuntansi Universitas Udayana, (25), 10341063.

Hadiwidjaja. (2001). Modal Koperasi. Bandung: CV. Pionir Jaya.

Hariwangsa, I. P. G. B., \& Wirawati, N. G. P. (2017). E-Jurnal Akuntansi Universitas Udayana KOPERASI Fakultas Ekonomi dan Bisnis Universitas Udayana ( Unud ), Bali , Indonesia Fakultas Ekonomi dan Bisnis Universitas Udayana ( Unud ), Bali , Indonesia ABSTRAK 2392 Pembangunan ekonomi harus didasarkan pada de, 20, 2392-2420.

Hery. (2012). Analisis Laporan Keuangan. Jakarta: PT. Bumi Aksara.

Horne, J. C. Van, \& John, M. (2012). Prinsip-prinsip Manajemen Keuangan Fundamentals of Financial Management. Jakarta: Lembaga Penernit Fakultas Ekonomi Universitas Indonesia.

Indrajaya, G. (2011). Akurat Jurnal Ilmiah Akuntansi Nomor 06 Tahun ke-2 September-Desember 2011.

Karjono, A., \& Fakrina, A. F. (2012). Pengaruh Perputaran Kas dan Perputaran Piutang Terhadap Rentabilitas Ekonomi pada KPRI di Lingkungan Bkn. Jurnal Ilmu \& Riset Manajemen, 15(2).

Kasmir. (2012). Analisis Laporan Keuangan. Jakarta: PT. Raja Grafinfo Persada.

Laksono, R. A. (2013). Pengaruh Likuiditas dan Solvabilitas Terhadap Rentabilitas pada KPRI Bakti Husna pada Tahun 2008 - 2012.

Menuh, N. N. (2002). Pengaruh Efektivitas dan Efisiensi Penggunaan Modal Kerja Terhadap Rentabilitas Ekonomi pada Koperasi Pegawai Negeri Kamadhuk RSUP Sanglah Denpasar. Jurnal Forum Manajemen , 6, 86-96.

Miftahul, S. (2011). BNP Paribas Siap Salurkan Kredit US\$ 600 Juta ke Sektor Tambang. Retrieved from https://finance.detik.com/moneter/d-1659961/bnpparibas-siap-salurkan-kredit-us-600-juta-ke-sektor-tambang.

Nisa, F. (2012). Analisis Efisiensi Modal Kerja Dan Pengaruhnya Terhadap Rentabilitas Ekonomi Pada KPRI Di Semarang. Skripsi Fakultas Ekonomi 
Universitas Negeri Semarang.

Nugroho. (2009). Penjualan , Perputaran Modal Kerja, Ukuran Perusahaan Dan Leverage Terhadap, 1-30.

Nurfarkhana, A. (2015). Pengaruh Modal Kerja Terhadap Laba Usaha Pada Koperasi Serba Usaha Sejati Mulia Jakarta, 7(3), 181-186.

Owolabi, S. A., \& Alu, C. N. (2012). Effective Working Capital Management And Profitability: A Study of Selected Quoted Manufacturing Companies in Nigeria. Economics and Finance Review, 2(6), 55-67.

Rembeth, D. (2015). PwC: Tahun 2015 Sebagai Tahun Terburuk Bagi Sektor Pertambangan. Retrieved from https://www.pwc.com/id/en/mediacentre/pwc-in-news/2016/indonesian/pwc---tahun-2015-sebagai-tahunterburuk-bagi-sektor-pertambangan.html.

Riyanto, B. (2001b). Dasar - Dasar Pembelanjaan Perusahaan.

Saravanan, S. and Ramganesh, S. (2013). An Empirical Study on Effects of Working Capital on Profitability (With Special Reference to Associated Cement Companies Limited). Indian Journal Of Applied Research, 3, 46-48.

Sari, P. I. P., \& Abundanti, N. (2014). Pengaruh Pertumbuhan Perusahaan Dan Leverage Terhadap Profitabilitas Dan Nilai Perusahaan. Jurnal Ekonomi Dan Bisnis Universitas Udayana, 2, 1427-1441.

Sujoko, \& Soebiataro, U. (2007). Shareholding Structure influence Leverage Factor Internal And External Factors Against Value Company (empirical study on the manufacturing and non-manufacturing companies in Jakarta Stock Exchange). Journal of Management and Entrepreneurship, 9(1976), pp.41-48. https://doi.org/10.9744/jmk.9.1.pp. 41-48

Supriadi, Y., \& Sofyana, A. (2012). Analisis pengaruh likuiditas dan solvabilitas terhadap rentabilitas pada koperasi karyawan pln cipta usaha, 12(2), 186192.

Takarini, N., \& Ekawati, E. (2013). Analisis Rasio Keuangan dalam Memprediksi Perubahan Laba Pada Perusahaan Manufaktur di Pasar Modal Indonesia. Ventura, 6 .

Warsidi, \& Pramuka, B. A. (2000). Evaluasi Kegunaan Rasio Keuangan Dalam Memprediksi Perubahan Laba di Masa Yang Akan Datang. Jurnal Akuntansi Dan Ekonomi, 2.

Wasis. (1993). Pembelanjaan Perusahaan. (UKSW, Ed.). Salatiga. 
Wibowo, A., \& Wartini, S. (2012). Efisiensi Modal Kerja, Likuiditas Dan Leverage Terhadap Profitabilitas Pada Perusahaan Manufaktur Di Bei. Jurnal Dinamika Manajemen, 3(1), 49-58. https://doi.org/10.15294/jdm.v3i1.2459 